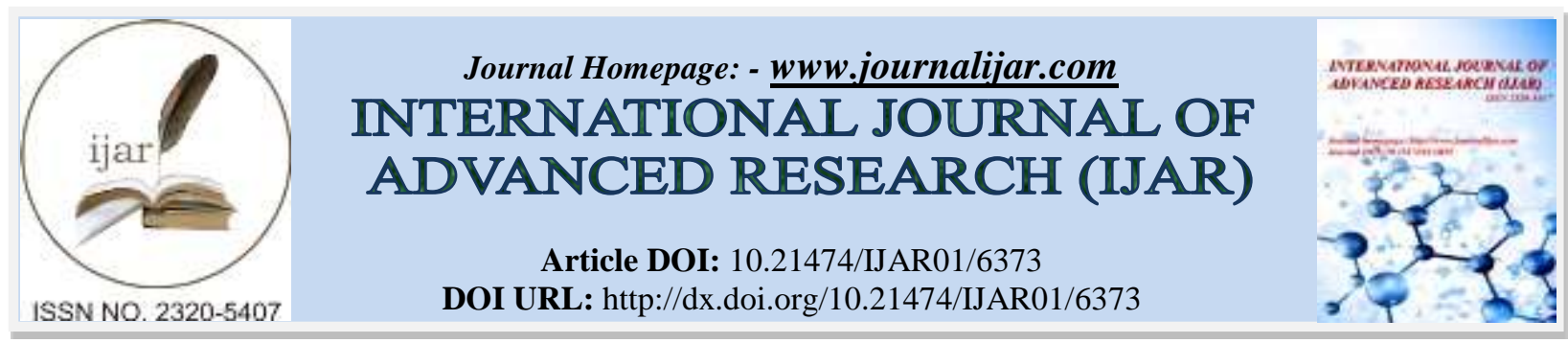

RESEARCH ARTICLE

\title{
THE INFLUENCE OF MANAGEMENT CAPABILITIES AND LEADERSHIP STYLE OF SCHOOL PRINCIPAL TOWARDS TEACHERS PERFORMANCE AT ENSINO SECUNDÁRIO GERAL DILI, TIMOR LESTE.
}

\author{
Antoneta Kuara. \\ Reg. Id.16.11.06.0023 Graduate of Education and Social Science. Post Graduate Program, Nusa Cendana \\ University, 2017.
}

\section{Manuscript Info \\ Manuscript History \\ Received: 21 November 2017 \\ Final Accepted: 23 December 2017 \\ Published: January 2018}

Key words:-

Management Capabilities, Leadership

Style, Performance Teachers.

\begin{abstract}
"The Influence of Management capabilities and Leadership style of School Principal towards teacher's Performance at Ensino Secundaria Geral Dili, East Timor". Supevisor:(I) Dr.Andy Nabu Sogen, M. Pd, (II) Dr. Geradus Uda.M.Pd.

This study aims to determine the magnitude of the influence of management capability and leadership style of school principal towards teacher's performance. Hypothesis in this research are: (1) there is an influence of management capability towards teachers' performance, (2) there is a performance influence of school principal's leadership towards teachers' performance, (3) there is influence of management capability and school principal's leadership style simultaneously towards teachers' performance.

The populations of this study are teachers and school principals of high school in Dili, Timor-Leste in 2017. The samples of this study are 100 teachers and school principals taken by proportional random sampling technique. Data collection of this research was conducted by using questionnaire method, with 80 items test. Meanwhile, the data analysis is used descriptive quantitative method with statistical techniques, simple correlation and regression analysis, and multiple correlation andregression analysis.

The result of this research are: (1) there is an influence of management capability towards teachers' performance, (2) there is a performance influence of school principal's leadership towards teachers' performance, (3) there is influence of management capability and school principal's leadership style simultaneously towards teachers' performance, this is indicated by the value of double correlation coefficient of 0.256 or the coefficient of determination of $6.554 \%$.
\end{abstract}

Copy Right, IJAR, 2018,. All rights reserved.

\section{Introduction:-}

Education is a major factor in the formation of a qualified person to face competition into a highly competitive of era globalization both in the field of education and technology, so the need for change and development in the world of education.

Corresponding Author:- Antoneta Kuara.

Address:- Reg. Id.16.11.06.0023 Graduate of Education and Social Science. Post Graduate Program, 1459 Nusa Cendana University, 2017. 
School as a formal educational institution serves to prepare human resources and is an important component in development in all field. Schools as educational organizations seek to examine their strengths and weaknesses by making sustainable improvements that can identify challenges and threats in improving the quality of student education. The quality of education is influenced by several factors and one of them is the management capability and the school principal's leadership style towards teachers' performance.

Teacher performance can be seen from work process or work result. A job always has steps (procedure), work procedures always lead to improvement of work results in accordance with work demands. If a job is done in accordance with the procedure, it will arrive at the desired work. The benchmark of performance is the job demands that describe the work to be achieved. How far a person is able to do the work then compared to the achieved result is called a person's performance on the job.

School-Based Quality Improvement is the autonomy of school management and participatory decision-making to achieve school quality objectives. Through this system, school managers are authorized to organize and improve the educational process on their own initiatives, thereby reducing the dependence of the central government. The above understanding shows that the school has greater authority to manage the school, because the school knows more about its strengths, weaknesses, opportunities, and threats so that it can optimize the utilization of available resources to advance its schools" (Ditjend Dikdasmen 2000).

The demand for principals with strong management skills and leadership styles is in fact inseparable from issues of educational praxis as well as issues related to decentralization of education, namely: a) limited authority of principals which implies the low effectiveness of achieving education targets in schools. This issue also concerns the lack of authority given to the principal in developing the management of school education including the limitation of his space in utilizing the sources of education allocated to schools (Soebagyo, 2002).

In the case of transparency, accountability of school management, the principal as manager in managing and managing his school should pay attention to school management inputs including: clear tasks, detailed and systematic plans, programs that support the implementation of school citizens to act, and the existence of control systems effective and efficient quality to ensure that agreed targets are achieved (DG D Dikdasmen, 2002).

One of the main aspects that are closely related to the performance of principals is seen from the level of management success and principal leadership influence on the improvement of teacher and employee performance that participates in improving student achievement toward quality improvement based on shared vision and mission of the school.

Formulate the following research problems: 1) How much influence of the school principals' management capability towards teachers' performance 2) How much influence the school principal's leadership style towards teachers' performance. 3) How much influence of the management capability and leadership style of school principals towards high school teachers' performance in Dili City.

The research objectives are: 1) to know the influence of school principals management capability towards teachers' performance. 2) To know the influence of school principals' leadership style towards teachers' performance. 3) To determine the influence of management capability and leadership style of school principals' towards high school teachers' performance in Dili City.

\section{Materials and Methods:- \\ Material:-}

Management is "the capability and special skills to perform an activity either with others or through others in achieving organizational goals" (Sudjana, 2000). The notion of management is also called by Stoner (Sudiyono, 2004) that "management is the process of planning, organizing, directing, and controlling the efforts of members of the organization and the use of other resources within the organization, in order to achieve the stated objectives".

Managerial activities according to Fayol (Nanang, 2000) included planning, organizing, commanding, coordinating, and supervision. In addition, managerial activities are also part of the implementation of "administrative functions in management consisting of planning functions, organizing functions, including staffing, implementation including direction, guidance, coordination and communication, budgetary function, and supervisory function" (Hadari, 2000). 
1) Planning is the process of setting goals or targets to be achieved and establishing the path and resources necessary to achieve those goals as efficiently and effectively as possible" Kauffman (Nanang, 2000). 2) Organizing (organizing), means an activity to design and establish the components of the implementation of a process of activity (Sudjana, 2000). 3) Supervision is the process of determining what is achieved, what standards are generated, that is implementation, assessing the implementation and when necessary to take corrective action so that the implementation can run according to plan that is in accordance with Terry's standards (Burhanuddin, 1994). The monitoring process, according to Murdick (Nanang, 2000) includes three stages, namely "1) setting implementation standards, 2) measuring the implementation of work compared to standard 3) determining the gap (deviation) between standard and plan implementation.

Three important things related to the principal as a manager is the process, utilization of all sources of the organization, and the achievement of organizational goals to be chieved.Process is a systematic way of doing things.

The process here is the use of management inputs that must be carried out by the principal consisting of "tasks, plans, programs, regulations (provisions, limitations, working procedures, etc.") (Ditjen Dikdasmen, 2002). The school's resources include the utilization of funds, equipment, information and human resources. Thus the principal's managerial capability is the implementation of planning, organizing, coordinating, monitoring and evaluation of educational resources in order to achieve the established school goals.

The principal function of a leader is to deal with problem solving and relate to coaching Stoner's group (Wahjo dumidjo, 2001). In solving the problem a leader advises and contributes information and opinions whereas in the case of group coaching, which includes the leader helping the group operate more smoothly, a leader approves or equips other group members, for example bridging the disputing group and paying attention to the discussions.

Another opinion that Selznick said that there are four functions of a leader (Wahjosumidjo, 2002), namely: (1) defining the mission and role of the organization, in this case the leader as a visionary; (2) manifestation of organizational goals, means that leaders must create wisdom into the order or decision of the means to achieve the planned objectives; (3) maintaining the integrity of the organization, which means the leader represents the organization to the public and to its devoted just as the leader tries to invite his subordinates to follow his or her decision to make the function work; and (4) controlling internal conflicts within the organization. Therefore the effectiveness of school management is highly dependent on the capacity of the principal as a central actor in playing the role. Here the principal should be able to: (1) manage existing school resources by providing full support to teachers, providing teaching materials and maintaining existing facilities; (2) provide sufficient time to manage and coordinate the instructional process; (3) establish regular communication with staff, students, parents and the community.

Based on the understanding, theory, and style of leadership then in this study the leadership of the principal is focused on the implementation of tasks in connection with the function as a leader. The task performed by the principal is to influence and mobilize the people who are led to achieve school goals through the use of influence of authority, the transformation of vision and mission, empowerment, motivation, direction and guidance, and the formation of commitment.

Managerial and leadership abilities must make two sides of the coin inseparable in the principal's performance. Weak one side will cause various problems. To better understand the differences between leaders and managers, Warren and Bennis make a list of differences, namely: 1) Managers take care of administration, leaders make innovation. 2) The manager is a copy, the leader is genuine; 3) Managers nurture, leaders develop; 4) Managers focus on systems and structures, leaders focus on people. 5) Managers rely on control, leaders inspire trust. 6) The manager has a short-term view, the leader asks what and why. 7) The manager shows his eyes, to the bottom line, the leader shows his eyes to the horizon.

Principles of leadership in general include: 1. Constructive principals should provide encouragement and coaching to every teacher and staff to develop their abilities optimally. 2. The principal's creative does not get stuck with the old work patterns that the previous school principal does, but he must always be creative in finding new ideas for his work. 3. Participation gives trust to all parties to always be involved in every school activity. 4. Cooperative: the principal must always cooperate with all the components involved in carrying out each activity. 5. Delegated: the principal seeks to give trust to the staff to perform the task in accordance with the ability and description of the task. 
6. Integrative: to produce a great energy, the principal must integrate all of its activities so that school goals can be achieved. 7. Rational and objective: the principal seeks to be a wise leader in carrying out his duties and acting on rational and observer considerations, not emotionally. 8. Pragmatic: principals in establishing policies and targets should base on the real conditions and capabilities the school has. Do not force yourself to perform activities beyond the capabilities and targets. 9. Example: the principal as a figure who deserves to give exemplary to all staff, teachers and students. 10. Adaptable and Flexible: principals must be adaptable and flexible in dealing with new situations and also create working conditions that support staff to adapt quickly.

\section{Method:-}

The approach of this study is a quantitative approach where information is collected from respondents using questionnaires or questionnaires. The subject of research is the performance of the teacher while the object of research is the management capability and the leadership style of the senior high school principal in Dili. The research is intended to obtain information about the management capability and leadership style of the school principal. To explain the research variables are done by descriptive and correlative method. Descriptive method aims to describe the findings of independent variables from research on management skills, principal leadership style, and teacher performance. While correlative method is used to find correlation between variable of headmaster management ability and variable of headmaster leadership style to teacher performance variable used correlation method.

There are two variables in this study independent variable of principal management capability (X1) and leadership style of headmaster style (X2), and while the dependent variable is teacher performance variable (Y).

The populations of this study are all teachers and school principals of the four senior high schools in the city of Dili as many as 170 people as an analysis unit spread over 4 high schools in Dili. The samples of the research is taken by senior teachers whose work period is above 5 years and have S1 degree to avoid the subjectivity of the assessment on the principal. Because of the large population, this study using the sample. The number of samples determined by Krejce table (Sugiyono, 2016) Based on the table with the number of population at the error rate of $5 \%$ obtained a sample of 100 teachers.

Sample with the proportional technique and random sampling, the proportional technique was used to determine the number of samples from each of the respondents who were randomly assigned to 4 schools in Dili, while the random sampling technique used was simple random sampling, ie the samples taken by lottery to all populations in a school.

Techniques the collection of valid research data performed steps namely the development of instruments, instrument determination, data collection and test instrument research. The research data were collected by questionnaire. Questionnaires are directed to teacher respondents and school principals to obtain data on school principal management capability (X1) and leadership style of school principal (X2), teachers' performance (Y) teachers and school principal.

Test Validity is done to test whether there is suitability between the parts of the instrument with the instrument as a whole. With the use of internal validity test is done by correlating between each item question to the total score. To obtain valid test results. Validity test results, with the following results. 1) the variable of headmaster's management ability, by looking at the table of validity is known the value of correlation coefficient $\left(r_{\text {count }}\right)$ is 0,657 can be concluded that all correlation coefficient value $\left(r_{\text {count }}\right)$ each question item bigger than at value ( $\left.r_{\text {table }}\right)$ at significance level $5 \%$ and $n=100$ is 0.195 , so that the whole question item in the principal management capability variable is valid. 2) the principal leadership style variable is known that the value of correlation coefficient $\left(r_{\text {count }}\right)$ is 0,496 can be concluded that not all correlation coefficient value $\left(\mathrm{r}_{\text {count }}\right)$ each question item bigger than value $\left(\mathrm{r}_{\text {table }}\right)$ at $5 \%$ significance level and $n=100$ is 0.195 , because there is a coefficient value of corelation smaller than 0.005 and 0.006 so that the whole item of question in principal leadership style variable there are still two invalid statements. 3 ) the teacher performance variable is known that the value of correlation coefficient $\left(r_{\text {count }}\right)$ is 0,393 can be concluded that all correlation coefficient value $\left(\mathrm{r}_{\text {count }}\right)$ each question item is bigger than the value $\left(\mathrm{r}_{\text {table }}\right)$ at $5 \%$ significance level and $n=100$ is 0,195 , so the whole item question in the teacher performance variable is valid.

Test Reliability used is the internal reliability by analyzing the consistency of the items on the instrument with a particular technique. In this research the reliability test is done by one shot or one measurement only. A variable is said to be reliable if it gives Cronbach Alpha value > 0.60 (Suharsimi, 1998). By looking at the value of alpha 
coefficient on each variables studied seen that the variable of principal management capability of 0.707 leadership style of 0.632 , variable and for teacher performance variables of 0.634 all coefficient alpha value greater than the critical coefficient, so the question items each variable is reliable.

Data analysis techniques used are. 1) Descriptive statistics to know the mean score of each variable, median, mode, maximum score score, as well as minimum score score. 2) Simple regression analysis is used to know the relationship model and the influence of each independent variable to dependent variable (teacher performance). 3) Multiple regression analysis is used to know the correlation and the influence of each independent variable simultaneously to the dependent variable (teacher performance). 4) Partial correlation coefficient to see the correlation coefficient between the independent variable controlled by other independent variables. If the partial correlation coefficient is large, then the relationship between the two variables is purely.

\section{Results And Discussion:- \\ Results:-}

The result of this research hypothesis X1 reads: "there is influence between principal management ability with teacher performance". The result of analysis shows that the relationship model for management ability (X1) with teacher performance $(\mathrm{Y})$ is expressed by regression equation $\mathrm{Y}^{\prime}=129,949+0,248 \mathrm{X} 1$. While the mean of the model is shown with $\mathrm{F} 0=5,194$ with $(\mathrm{p})=0,000$. The linearity test relation between management ability $(\mathrm{X} 1)$ with teacher performance $(\mathrm{Y})$ expressed in the form of statistical test result $\mathrm{F} 0=2,279$ with $(\mathrm{p})=0,025$. These results indicate that the research hypothesis of teacher performance is influenced by the ability of acceptable management of truth with linear relationship model. With regression equation it can be understood that every increase every one unit of management ability hence increase of teacher performance equal to 0,248 at constant of 129,949 . The strength of the relationship between management ability and teacher performance, expressed by the correlation coefficient of $r_{x 1 y}=$ 5,194 with $(p)=0,000$. That means the research hypothesis that states there is a relationship between the ability of management and teacher performance can be accepted truth. Thus the higher the management ability will be the higher level of teacher performance. The amount of contribution of management ability to teacher performance got partial correlation coefficient equal to 0,224 or coefficient of partial determination equal to $\left(\mathrm{r}_{2} \times 100 \%\right)=0,2242 \mathrm{x}$ $100 \%=5,018 \%$. This means that one of the determinants of whether or not the performance of high school teachers in Dili City is the ability of the principal's management. If the principal's management ability is high then the teacher's performance will increase, and vice versa if the principal's management ability decreases, then the teacher's performance will decrease as well.

The research hypothesis on X2 reads: "there is an influence between the school principals' leadership style and teachers' performance". The result of the analysis shows that the relationship model for principal leadership style (X2) with teacher performance $(\mathrm{Y})$ is expressed by regression equation $\mathrm{Y}^{\prime}=133,977+0,104 \mathrm{X} 2$. While the mean of the model is shown by $\mathrm{F} 0=1,124$ with $(\mathrm{p})=0,292$. The linearity test of relationship between principal leadership style (X2) and teacher performance (Y) is expressed in the form of statistical test result F0=1,060 with (p) = 0,292. These results indicate that the research hypothesis that states teacher performance is influenced by the principal leadership style can be accepted truth with linear relationship model. With regression equation it can be understood that each increase every one unit of headmaster leadership style hence increase of teacher performance equal to 0,104 at constant 133,977 . The strength of the relationship between principal leadership and teacher discipline, expressed by the correlation coefficient of $\mathrm{r}_{\mathrm{x} 2 \mathrm{y}}=1.124$ with $(\mathrm{p})=0.292$. That means the research hypothesis that states there is influence between the leadership of the principal and the teacher's performance is acceptable truth. Thus, the better of the performance of the school principals' leadership the better of the teachers' performance. The amount of contribution of influence of headmaster leadership style to teacher performance got partial correlation coefficient equal to 0,106 or partial determination coefficient equal to $\left(\mathrm{r}_{2} \times 100 \%\right)=0,1062 \times 100 \%=1,124 \%$. This means that one of the determinants of whether or not the performance of high school teachers in Dili is the leadership style of the principal. If the headmaster's leadership is good then the performance of high school teachers in Dili will increase, and vice versa if the principal leadership style is not good, then the performance of high school teachers in Dili will also be less good.

The relationship of management capability and school principal leadership style towards the performance of teachers, High School in Dili City were 0.258 and 0.121 respectively, while the partial correlation coefficient was 0.234 and 0.124 , respectively. It appears that the partial correlation coefficient of management capability is higher than that of the school principals' leadership style. The relationship of influence simultaneously together between principal management capability variables (X1), and leadership style headmaster variables (X2) with teacher 
performance variables (Y) as follows. The result of multiple regression analysis got the coefficient of multiple correlations (R) equal to 0,066 with coefficient of determination $\left(\mathrm{r}_{2}\right)$ equal to 0,256 or $6,554 \%$. The rest is influenced by other factors. Fregres value of 226,581 with a significance of 0.274 . The regression equation is: $Y^{\prime}=110,345+$ $0,258 \mathrm{X} 1+0,121 \mathrm{X} 2$, while the regression coefficients are partially like product moment correlation coefficient of management ability and principal leadership style toward high school teacher performance in Dili City respectively are 0.224 and 0.106 , while the partial correlation is 0.235 and 0.127 respectively. It appears that the partial correlation coefficient Ability of the principal's management is higher than the variable the school principals' leadership style.

Hypothesis test was conducted to find correlation between variable of school principals' management ability (X1) with teacher performance variable (Y), headmaster leadership style variable (X2) with teacher performance variable $(\mathrm{Y})$, and simultaneous relationship between variables free (X1), (X2), with the dependent variable (Y). Adapu of hypothesis test is as follows: 1) the influence of management ability with high school teacher performance in Dili city found that the coefficient of partial correlation of school principals' management towards high school teacher performance in Dili City of Principal Management (X1) and Principal Leadership (X2) Teacher Performance (Y) $r_{x 1 . y}=0.258 r_{x 2 y}=0.121 r_{x 12 y}=110,345$ Regression equation: $Y^{\prime}=110,345+0,258 X 1+0,121 X 2$ Freg $=0,124$ Sig. $(p)=0,037$ Dili equal to 0,248 with regression coefficient equal to 0,258 , $t$ value equal to 14,741 and significance ' $p$ ' 0.000 meaning null hypothesis accepted because significance $t(p)$ is more than significance level $\alpha=0,05$ thus that alternative hypothesis is being tampered with by other factors, this means that there is a significant effect of management ability with high school teacher performance in Dili City with partial correlation coefficient of 0.235 or partial coefficient of determination of $\left(\mathrm{r}_{2} \times 100 \%\right)=0,2242 \times 100 \%=5,018 \%$. Whether or not the performance of high school teachers in Dili can be determined by the capability of the school principals management, the higher the principal's management ability the high school teacher performance in Dili will be better and vice versa if the principal's management ability is low, then the teacher's performance in Dili will also be low also. 2) the influence of headmaster's leadership style with high school teacher performance in Dili City was found that partial leadership coefficient of headmaster leadership toward high school teacher performance in Dili City Leadership Style of Principal (X2) and Principal Management Capacity (X1) $\mathrm{r}_{\mathrm{x} 2 . \mathrm{y}}=0.121 \mathrm{rx} 1 . \mathrm{y}=0.248 \mathrm{r}_{\mathrm{x} 12 \mathrm{y}}=110,345$ Regression equation: $\mathrm{Y}^{\prime}=110,345+0,258 \mathrm{X} 1+0,121 \mathrm{X} 2$ Freg $=1,124$ Sig. $(\mathrm{p})=0,0292$ Dili equal to 1,124 with regression coefficient equal to $0,104, \mathrm{t}$ value equal to 8,852 and its significance $(\mathrm{p}=0.000)$ meaning null hypothesis accepted because significance $t(p)$ more than significance level $\alpha=0,05$ which shows that $t$ calculations are in the acceptance area of Ho, hence that the alternative hypothesis is rejected which means there is a significant influence of principal leadership on high school teacher discipline in Dili with partial correlation coefficient of 0.106 or partial determination coefficient of $\left(r_{2} \times 100 \%\right)=0.1062 \times 100 \%=1.124 \%$. This means that one of the determinants of whether or not the performance of high school teachers in Dili is the leadership style of the principal. If the leadership style of the principal is good then the performance of high school teachers in Dili City will be better and vice versa if the leadership style of the principal is not good, then the performance of high school teachers in Dili city will also be less good as well. 3) the influence of management ability and principal leadership style on high school teacher performance in Dili City simultaneously in getting model of multiple regression equation: $\mathrm{Y}^{\prime}=0,058$ $+0,476 \mathrm{X} 1+0,504 \mathrm{X} 2$; with Freg of 3,412 and its significance (probability) $=0,037$. The results show that Ho is simultaneously received because (sig F/p) is 0.037 more than the significance level $\alpha=0.05(5 \%)$. With the acceptance of Ho means alternative hypothesis $(\mathrm{Ha})$ in this study is rejected, that is there is significant influence simulant management ability, leadership style headmaster, to the performance of high school teachers in Dili with the coefficient of determination of $6.554 \%$. Capability and leadership style of the school principals can determine whether or not the teacher performs well, so the performance of the teacher will be good if influenced by management capability and good school principal leadership style as well.

\section{Discussion:-}

Based on the result of the research of the influence of the management's capability and the school principals' leadership style on the performance of high school teachers in Dili City are as follows: 1. Influence of Management Ability towards Performance of Teacherss. The result of research proves that there is significant influence of school principal management capability towards high school teachers performance in Dili $(\mathrm{p}=0,025)$ and partial correlation coefficient equal to 0,224 or coefficient of determination $5,018 \%$, which means that goodness of capability of headmaster's management influence to goodness of high school teacher performance in Dili, better headmasters; management acapbility will improve performance of high school teacher in Kota Dili and vice versa if the principal's management ability is not good, then high school teacher performance in Dili city will also be low also. 
The results can be understood because if the principal has good management skills will be able to manage human resources including teachers in the school to be good as well. This result is in line with the theory that management activity is essentially a series of managerial activities undertaken by a manager who cannot be separated from the implementation of the functions of management itself. Managerial activities according to Fayol (Nanang, 2000) include planning, organizing, commanding, coordinating, and supervision. In addition, managerial activities are also part of the implementation of "administrative functions in management consisting of planning functions, organizing functions, including staffing, implementation including direction, guidance, coordination and communication, budgetary functions and supervisory functions" (Hadari, 2006). It is clear that if the principal has good management skills it will be able to plan, organize, coordinate, coordinate, and supervise properly, and surely the teacher can work as well as possible in accordance with his duties and responsibilities. 2. Effect of Principal Leadership Style on Teacher Performance of the research results proves that there is a significant influence of principal leadership style on high school teacher performance in Dili City $(\mathrm{p}=0,292)$ and partial correlation coefficient of 0,106 or coefficient of determination $1,124 \%$, which means that good whether or not the leadership style of the principal influences the goodness of the high school teacher performance in Dili, the better the principal's leadership style will improve the performance of high school teachers in Dili and vice versa if the principal leadership style is poor, then the high school teacher performance in Dili will also be low also.

The result can be understood because it is in line with the theory that the scchool principals' leadership is also a capability and readiness of the school principal to influence, guide, direct and mobilize school staff in order to work effectively in order to achieve the predetermined educational and teaching objectives (Ditjend. Dikmenum, 2002). According to Koonz and Doonel (Burhanudin, 1994) the capabilities are intended to consist of four elements, namely: (1) authority or leader power, (2) ability to integrate human resources with varying motivational forces at all times and situations, (3) ability in developing work climate so as to generate motivation, and (4) ability in developing appropriate leadership styles. Obviously if the principal has a good leadership style will be able to lead the teacher as his subordinates well that teachers will all too show good performance as well. 3. Simultaneous Influence Management Capability and Style of School Principals' Leadership towards Teachers' Performance of the results of hypothesis testing and testing simultaneously proves that there is a significant influence simultaneously towards management capability and leadership style of school principal towards high school teacher performance in Dili City $(p=0,037)$ and coefficient of determination equal to 6,554\%. This means that the performance of high school teachers in Dili City can be determined by the principal leadership style and management skills received by teachers simultaneously by $6.554 \%$. while the rest equal to $93,554 \%$ more high school teacher performance in Dili city is determined by other factors outside of variable in this research model such as factor needed by principal in carrying out its duty is support from government, whether in the form of coaching or material support, do not see political factor in appointment of a heads of schools, but in fact more government support is focused on teachers than on principals, whereas school principals are the key to school success. The lack of government support is what causes the headmaster's job to become heavier.

The results of this study proves the capability of management and leadership style of the principal in saying good and true if able to bring improvement and change attitudes and behavior of subordinates (in this case the teacher). Changes in teacher attitudes are characterized by high teacher commitment and loyalty to the principal, high teacher motivation in performing their duties, and feelings of satisfaction felt by teachers. While the change in teachers' behavior indicated by the involvement or achievement, support and willingness of teachers to run various tasks given by the principal.

Through the capability of management and leadership style of the school principal is high it will improve the performance of subordinates. Thus it can be said that management ability and leadership style of principal correlate positively with teacher performance. That the goodness of the management capability and the school principals' leadership style influences the goodness of the high school teacher performance in Dili City, the better the management ability and leadership style of the principal will improve the performance of high school teachers in Dili City and vice versa if the management cability and leadership style is not good, then the performance of high school teachers in Dili will also be low.

Thus to see from the results of this study then to improve the quality of education, especially high school in Dili begins with the increased ability of professional principals in order to improve teacher performance that result directly to the quality of learning that ultimately can improve the achievement of high school students in Dili. It is not excessive if the results of this research as input for policy makers in the field of education in particular to 
improve the capability of the school principals in various ways, either through scientific meetings, training and how to recruit new principals to pay more attention to the standardization of the ability to have a principal professional.

\section{Conclusion:-}

Based on the results of research and discussion on the Influence of Management Capacity and Style of Principal Leadership on Teachers' Performance at High School in Dili City, it can be concluded the following matters. 1) There is a significant influence between the capability of the school principals' management and the performance of high school teachers in Dili City, with partial correlation coefficient of 0.224 or partial determination coefficient of $5.018 \%$ which means that the better the principal's management ability will be betters also the performance of high school teachers in Kota Dili. 2) There is a significant influence between the principal's leadership style and the performance of high school teachers in Dili City, with partial correlation coefficient of 0.127 or partial determination coefficient of $1.613 \%$, which means that the better the headmaster's leadership style the better the high school teacher performance Dili City. 3) There is a significant influence simultaneously between Leadership Style and Principal Management Ability to High School Teacher Performance in Dili City, with multiple correlation coefficients of 0.256 or multiple determination coefficients of $6.554 \%$.

\section{THANKS GIVING}

My thanks the author to:

Advisors I and Advisors II who have been patient to guide, direct, and motivate authors in this study, 2) Team Editor Thomson Reuters who has provided assistance and direction so that this journal was finally be published, 3) All teachers and administrators of SMAN in Dili City for the time and participation in research conduct by the writer. 4) Fellow compatriot who motivated the author to complete this research. 5) IPS Education Study Program, especially Teacher Training, and 6) all parties who have provided assistance and support the writer.

\section{Bibliography:-}

Atmodiwiro, Soebagyo, (2003). Kepemimpinan kepala sekolah. Semarang: Adhi Waskita.

1. Burhanudin, (1994). Analisis administrasi manajemen dan kepemimpinan pendidikan. Jakarta : Bumi Aksara

2. __ (2002). Monitoring dan Evaluasi SLTP. Jakarta : Ditjend. Dikdasmen Depdiknas RI.

3. (2000). Rambu-rambu penilaian kinerja SLTP - SMU. Jakarta : Dikdasmen Depdiknas RI . Ditjend. Dikdasmen

$4 . \quad$, (2005). Kepemimpinan Kepala Sekolah. Jakarta PT. Raja Grafindo Persada

5. Hadari, (2000). Manajemen strategic dengan ilustrasi organisasi profit dan non profit. Jakarta : Rajawali Perss.

6. Hadari. (2006). Evaluasi dan Manajemen Kinerja di Lingkungan Perusahaan dan Industri. Yogyakarta: Gajah Mada University Press.

7. Nanang, (2000). Landasan manajemen kependidikan. Bandung : Remaja Rosdakarya.

8. Soebagyo, (2002). Kebijakan pemerintah propinsi Jawa Tengah dibidang pendidikan dalam era otonomi daerah, Makalah seminar revitalisasi pendidikan dasar dan menengah. Magelang : Univ. Muhammadiyah Magelang.

9. Suharsimi. (1998). Manajemen Penelitian. Yogyakarta: Rineka Cipta.

10. Sudjana D.,(2000). Manajemen program pendidikan untuk pendidikan luar sekolah. Bandung : Falah Production.

11. Sudiyono, (2004). Manajemen Pendidikan Tinggi. Jakarta : Rineka Cipta.

12. Sugiyono, (2016). Metode penelitian kuantitatif, kualitatif dan R\&D. Bandung : CV. Alfabeta

13. Wahjosumidjo, (2001). Kepala sekolah : Tinjauan teoritis dan permasalahannya. Jakarta : Rajawali Perss.

14. Wahjosumidjo. (2002). Kepemimpinan Kepala Sekolah Tinjauan Teoritik dan Permasalahannya. Jakarta: Raja Grafindo Persada. 